\title{
Article
}

\section{Sport as a vehicle for implementing corporate social responsibility: firms listed on the Warsaw and Moscow stock exchanges}

Anagnostopoulos, Christos, Lopez-Carril, Samuel and Zysko, Jolanta Available at http://clok.uclan.ac.uk/37095/

Anagnostopoulos, Christos ORCID: 0000-0001-7470-5191, Lopez-Carril, Samuel and Zysko, Jolanta (2021) Sport as a vehicle for implementing corporate social responsibility: firms listed on the Warsaw and Moscow stock exchanges. European Journal of International Management, 15 (2-3). pp. 367390. ISSN 1751-6757

It is advisable to refer to the publisher's version if you intend to cite from the work. http://dx.doi.org/10.1504/EJIM.2021.113271

For more information about UCLan's research in this area go to http://www.uclan.ac.uk/researchgroups/ and search for <name of research Group>.

For information about Research generally at UCLan please go to http://www.uclan.ac.uk/research/

All outputs in CLoK are protected by Intellectual Property Rights law, including Copyright law. Copyright, IPR and Moral Rights for the works on this site are retained by the individual authors and/or other copyright owners. Terms and conditions for use of this material are defined in the policies page. 


\title{
Sport as a vehicle for implementing corporate social responsibility: Firms listed on the Warsaw and Moscow Stock Exchanges
}

\section{Anagnostopoulos, Christos}

\author{
López-Carril, Samuel
}

\section{Żyśko Jolanta}

\begin{abstract}
:
This paper provides a descriptive account of the extent to which firms listed on the Warsaw (WSE) and Moscow (MSE) Stock Exchanges use sport for their corporate social responsibility agendas. Drawing on institutional isomorphism, we deductively categorised CSR through sport cases based on the framework developed by Bason and Anagnostopoulos (2015). A total of 1,317 documents were content-analysed, 442 from WSE firms and 875 from MSE firms. A total of 2,501 CSR-through-sport initiatives were reported over the five-year period studied (2013-2017) in the WSE case and 2175 in the MSE case. Our results show that internationally listed firms are increasingly embracing sport for their CSR programmes, with the 'personnel engagement' stream seeing a constant increase, followed by 'sponsorship' and 'philanthropic' initiatives. The young generation takes the lion's share when it comes to being the beneficiaries of these CSR programmes, whereas 'sport participation' constitutes the basis of most such programmes.
\end{abstract}

Keywords: corporate social responsibility, CSR, sports, isomorphism, stock exchange

Biographical notes: Christos Anagnostopoulos (PhD) is an Assistant Professor in Sports Business Management and the Deputy Head of Business and Management School at University of Central Lancashire (Cyprus) and an Associate Professor in Sport Management at Molde University College (Norway). His research interests lie in corporate social responsibility, governance, and more recently entrepreneurship and positive organisational behaviour in sport. Christos has (co)authored more than 40 peer reviewed international journal publications, 10 book chapters and has given more than 50 presentations in international conferences worldwide. He served at the Board of the European Sport Management Association as an elected member (20172019). Lately, Christos is being consulting the highest authority of sports in Cyprus on issues related to good governance and strategy.

Samuel López-Carril holds a BSc (Hons) degree in 'physical activity and sports sciences' (Universitat de València, 2012) and an MSc (Hons) in 'direction and management of physical activity and sport' (Universitat de València, 2016). He is currently a PhD student in physical activity and sport, researching about social media in sport management education. His studies are supported through a pre-doctoral contract "FPU15/05670" granted by the Spanish Ministry of Science, Innovation and Universities. Samuel's research and teaching interests lie in the areas of social media in sport management education, as well as in management of sports events and team sports organizations.

Professor Jolanta Żyśko is the Rector of Vistula School of Hospitality Management in Warsaw. She has authored and co-authored over 120 original 


\begin{abstract}
Author
scientific articles, book chapters and books in various outlets. She has been a member of the EU Expert Group on Human Resources Development in Sport (XG HR)(2014-2017), a member of the Board of European Association for Sport Management (2009-2015), quality expert for national and international accreditation, president of the Polish Organisation for Sport Managers (20092012) while, served as the President of the 2016 EASM conference. Her research interests lie in the organization of sport, sport marketing, sport events, and sport policy.
\end{abstract}

\title{
1 Introduction
}

Corporate social responsibility (CSR) has received significant research attention recently (Aguinis and Glavas, 2012), responding to or highlighting the need for increased CSR by companies of all types and sizes (Kudlak and Low, 2015). Multinational firms (Beddewela and Fairbrassas, 2016), as well as small and medium-sized enterprises (Amaeshi et al., 2016) from different industry sectors (Cordeiro and Tewari, 2015) and national contexts (Godfrey et al., 2010), have engaged with some sort of CSR. Definitions of CSR and how it is (or should be) done remain theoretically and practically challenging (Sheehy, 2015); nevertheless, the notion assumes a responsibility among firms to pursue their business-oriented goals, not just by without harming, but by benefiting the society at large (Porter and Cramer, 2006). Interestingly, although empirical evidence has suggested that such practice partly occurs to satisfy legitimation purposes (Du and Vieira, 2012), counteracting negative publicity (Vanhamme and Grobben, 2009), or even as a public relations exercise (Benn et al., 2010), companies also recognise CSR's capability for value enhancement (Malik, 2015) and competitive advantage (Porter and Kramer, 2011).

Whatever the reasoning, sport seems to be a distinctive platform for CSR implementation (Smith and Westerbeek, 2007). An increasing number of firms that exist and operate outside or in parallel to the sport industry have started manifesting their social responsibility through sport (Djaballah, Hautbois and Desbordes, 2017). This often occurs by innovative approaches (Hayduk III, 2020; Pounder, 2019; Ratten and Ferreira, 2016) that foster entrepreneurship at local, national and international level (Baier-Fuentes et al., 2019; Crespo and Aurélio, 2020) as well as social entrepreneurship in and through sport (Ahonen and Persson, 2020; Miragaia et al., 2017). In other words, without necessarily restricting their initiatives in the local communities where they mainly reside, more and more firms see meaning in employing CSR through professional sports teams (Sheth and Babiak, 2010), sport federations (Zeimers et al., 2019), sports charities (Anagnostopoulos et al., 2017; Kolyperas et al., 2016), athletes (Tainsky and Babiak, 2011), or sporting events (Batty, Cuskelly and Toohey, 2016), not least at international level (Ratten, 2011).

Despite this increased attention to CSR-through-sport from international firms, little is known about the extent to which these firms employ sport for their CSR agendas. Two notable studies are the exceptions in this regard. McDonald et al. (2009) were the first to look at the indexed multinational enterprises (MNEs) with the highest CSR performance rankings; they found that these firms are slowly but increasingly embracing sport for the implementation of their CSR programmes. Bason and Anagnostopoulos (2015) put more emphasis on longitudinality in order to form conclusions regarding the trend whereby the corporate world - and certain industries in particular - consider sport as their core theme 


\section{Sport as a vehicle for implementing CSR}

for displaying their socially responsible face in a specific set of stakeholder groups. However, a shortcoming of that study was that the yearly CSR reporting of the examined firms steadily increased over the decade under examination, as reflected by the number of CSR cases that had sport at their core. Therefore, one could question whether the reported trend is due to the increased interest by the firms to use sport for CSR or simply seen as such because the reporting is greater. Moreover, as 2012 was the last year of examination in the latter study, it is now timely to rectify the aforementioned shortcoming and make an updated descriptive account of whether sport remains one of the most preferred platforms for CSR deployment. To this end, the present paper examines the extent to which listed firms' CSR programmes have sport at their core. It does this by drawing on Bason and Anagnostopoulos' (2015) conceptual framework, and deductively assessing the nature, beneficiaries, and outcomes of CSR implementation through sport.

The paper is structured into five sections. Following this introduction, we discuss associated literature and present the theoretical foundations that underpin this study. We then provide a detailed account on the method employed to meet the purpose of this study. This is followed by the results of the study, discussion of the managerial implications, and suggestion of avenues for future research in relation to CSR-throughsport.

\section{Literature review and theoretical underpinnings}

\subsection{Corporate social responsibility and international management}

In an increasingly globalised business setting, MNEs develop CSR agendas that play an important function in their internationalisation process (Oh et al., 2019). The perception of the CSR's role has changed from some sporadic activities with a high altruistic nature or a charity element into a key part of modern strategic management (Kuznetsov and Kuznetsova, 2010). Thus, CSR can be envisioned as crucial feature by which MNEs, in different national settings (Rim et al., 2019), create legitimacy, a strong reputation and a competitive advantage (Filippov, 2012; Trąpczyński, 2018; Wang and Wang, 2018). Not least, in relation to the stock market returns (Eissa and Refai, 2018).

In the Spanish context, for example, Muñoz et al. (2015) studied the effect of CSR initiatives on financial performance of the 122 companies listed on the Madrid Stock Exchange. The authors found that CSR practices have a positive effect on financial performance, with the relationship being stronger for the company's long-term performance than its short-term performance. Chalkasra et al. (2019) reviewed theoretical perspectives of CSR among family enterprises and type of CSR practices adopted by these enterprises, linking this with internal aspects of the firms (such as organisational structure and size) and external aspects (global institutionalisation, regulatory frameworks, economic systems, etc.). CSR has been considered a key element in the internationalisation of the Russian firms, helping them expand to Western markets (Filippov, 2012), as a plausible solution to a trust deficiency between firms and the State, and as a tool that foster the competitiveness of these firms in the short term (Kuznetsov and Kuznetsova, 2008). Ertuna and Tükel (2010) looked at the CSR practices of 49 firms in an emerging market with a strong cultural tradition (Turkey) that is, at the same time, in the process of integration with the global markets that follow international principles of governance and CSR. The authors determined that the cultural context has an impact 


\section{Author}

on the nature of CSR practices, thereby having an influence in the interaction between local and international streams.

Comparative studies have also shed light on the role CSR has in the internationalisation of firms (among other processes). For example, CarrascoMonteagudo and Buendía-Martínez's (2013) study based on data from 32 countries found that the integration of CSR practices encourages firms' innovation and internationalisation, which has positive effects on business results and overall economic growth. They also stated that, in an increasingly global world, firms have to adopt strategic CSR to reach new market niches. Another notable study is Berg et al. (2018), which focused on three countries with similar institutional frameworks (Denmark, Germany and the Netherlands) and assessed possible similarities and differences regarding antecedents and outcomes of CSR practices. A total sample of 519 firms were analysed, founding a positive relationship between stakeholder constraints, CSR practices and business outcomes, with similarities in the results among the three counties. These similarities led the authors to support a pan-European approach of CSR, where the stakeholders' interests are similar in countries with similar institutional contexts.

The above indicative studies highlight, with varying degrees of explicitness, that CSR has become an essential part of MNEs towards legitimacy, brand reputation and competitive advantage. Where these studies fall short, however, is in delineating the nature of the reported CSR practice(s). In other words, how do these firms implement CSR in order to capitalise on the latter's increasing importance, in an increasingly international business environment where cultural differences cannot be downplayed? Sport seems to be one such implementation mechanism and this is where we now turn our attention.

\subsection{Corporate social responsibility and international sport management}

Sport is an international product and service that influences businesses on a global scale (Ratten, 2011). In the last decade or so, key scholars in the field have been pointing out that the CSR-sport nexus "is here to stay", not least in the context of corporations (Ratten and Babiak, 2010). This is largely because sport is a component of global culture and constitutes a significant part of many people's lives through regular active or passive engagement (Godfrey, 2009). As such, it can be used as a common cultural platform upon which CSR programmes are developed and implemented, without neglecting that such social interventions are context-dependent (Breitbarth et al., 2015). As Roome (2005) put it: "CSR agenda followed by leading companies in a country is influenced by many context-specific factors, but especially be cultural norms, traditions, rules and formal institutions of the country within which the country has its headquarter and by the historical development of societal governance operating in this country” (p. 323).

Although CSR should be approached as a context-specific tool for positive social change, Smith and Westerbeek's (2007) seminal study put forward some universal principles that apply specifically to the CSR and sport nexus. In particular, sport is classified as an ideal means for implementing and demonstrating socially responsible initiatives for various reasons. First, the popularity and global reach of sport can ensure that these practices have mass media distribution and communication power. Second, and relatedly, sport offers the perfect platform to encourage activity including health awareness and anti-obesity campaigns as well as disease prevention. Third, sport has youth appeal, so engaging children in programmes designed to tackle with or contribute towards various social issues becomes easier if such programmes are associated with a 


\section{Sport as a vehicle for implementing CSR}

sports organisation or a well-known athlete. Fourth and linked with the previous reason, social interaction can be facilitated by group participation in sports activities. Fifth, environmental and sustainability awareness and consciousness can be further reinforced especially with the hosting of major sporting events (Olympic Games, FIFA Soccer World Cup, etc.). Sixth and as a result of the previous point, sport may also lead to enhanced cultural understanding and integration. Finally, both active and passive participation in sport offers immediate gratification benefits with unclear social advantages, albeit barely unimportant.

Sport, however, should not be regarded as an unproblematic context (Morrow, 2012), much less a magic elixir (Inoue and Kent, 2012), this fusion of financial and symbolic power suggested by Smith and Westerbeek (2007) seems to be valid in the corporate world. Indeed, MacDonald et al. (2009) showed that CSR, through the sporting activities of these companies, is comprised primarily of sponsorship, followed by a focus on philanthropic funding, volunteers, health, disability, grassroots initiatives, underprivileged groups, and the environment. Levermore (2010) addressed the same subject from a more critical perspective, identifying some of the limitations involved in employing CSR-through-sport. For Levermore, although the sporting context provides a platform for building partnerships between institutions that would not normally work together, this development is most often driven by the needs of the donor (firms) rather than those of the community the programme is supposed to serve.

Spaaij and Westerbeek (2010) highlighted the same point as Levermore (2010). Although they acknowledged the potential for sport to create and maintain social capital through CSR-related activities, they also recognised that the aim of furthering corporate business objectives might be disproportional to the production of social capital (in favour of the former). For Spaaij and Westerbeek (2010), this favourability might be reasonable, to some extent, given the competitive business environment within which both firms and sports organisations operate. However, they underlined that "improved knowledge of the relationship between social gains and economic success may well lead to increasing investment in the achievement of social outcomes" (p. 1370). Levermore (2011) built on this observation by calling for fewer top-down quantitative approaches when evaluating these CSR-through-sport programmes, arguing that their diverse nature and sometimes "very loose objectives" (p. 352) did not lend themselves well to such appraisal.

These critical accounts on the CSR-sport nexus notwithstanding, international firms continue to consider sport as a platform for displaying their socially responsible face, which makes them look increasingly similar in how they engage with CSR. The next section offers some explanations on why this might be the case.

\subsection{Institutional isomorphism: sport as a mimetic and normative force?}

Institutional theories broadly investigate how social environments influence organisations (Campbell, 2007; Greenwood et al. 2008). The key proposition in institutional theory is that firms tend to behave increasingly similar over time as they collectively integrate templates and signals from the institutional environment for legitimacy-seeking purposes (DiMaggio and Powell, 1983). Institutional isomorphism describes how environments pressure firms to become more similar via coercive, mimetic, and normative forces (DiMaggio and Powell, 1983). Coercive forces represent the influence that external regulatory agencies have on the firm. Mimetic forces occur 
Author

when similar firms adopt successful characteristics from competing firms. Normative forces are pressures that various stakeholder groups (for example, the media, interest groups, employees) exert to practice certain social norms. In essence, normative isomorphism takes place when firms internalise the norms that derive from the professionalisation of a field (DiMaggio and Powell, 1983).

Given the potential impact of the institutional environment, our view is that institutional theory can potentially help explain firms' behaviour, including CSR behaviour, through sport. First, we assume that sport can be seen as a "recipe" for best practices in and across the field in which firms exist and operate. When designing CSR programmes, firms look at and mimic what like-minded firms do, less so for businesscompetition than for content-inspiration. At the same time, while sport enjoys a strong perceived image of social legitimacy (Godfrey, 2009), the sports industry is increasingly adopting professional practices and strategic approaches in embracing CSR (Breitbarth et al., 2015). Together, these two factors constitute a powerful set of normative forces that firms outside sport can hardly ignore when it comes to formulation and implementation of CSR initiatives. Therefore, assuming that it is unlikely that coercive pressures exist for specifically employing sport for the delivery of CSR, this paper draws theoretical inspiration from mimetic and normative forces to explain why firms are increasingly including sport as the core theme for their CSR agendas.

\section{Method}

\subsection{Content analysis}

The most common technique for assessing a firm's CSR disclosure is content analysis (Gray et al. 1995; Papacharalampous et al., 2019). This technique is defined as "a method of codifying the text (or content) of a piece of writing into various groups (or categories) depending on selected criteria" (Milne and Adler, 1999, p. 237). Content analysis is a research technique used to examine the presence of certain words or concepts within a fragment of text (Sweeney and Coughlan, 2008). However, it is crucial to determine the set of standardised rules about "what" and "how" to code, measure and record (Gray et al., 1995; Milne and Adler, 1999) so that any independent judge would be able to search for and identify what has (and has not) been qualified in the data (Gray et al., 1995). Similar to Bason and Anagnostopoulos (2015), the present paper also draws on the Council of Europe's (1992) European Sports Charter, which defines "sport" as "all forms of physical activity which, through casual or organised participation, aims at improving physical fitness and mental well-being, forming social relationships, or obtaining results in competition at all levels". We also followed the work of McDonald et al. (2009) as guidance in the coding process. As such, apart from word "sport", we also searched for the words "health", "disability", "volunteers", "athletes", "grassroots" and "funding" in order to explore potential connections with the notion of sport as defined above that have not been explicitly mentioned in the examined parts of the reports under examination.

\subsection{Research setting, sample and coding procedures}

We examined CSR-through-sport within MNEs listed on the Warsaw and Moscow Stock Exchanges. The rationale for choosing this particular research setting was twofold. First, as Poland and Russia are considered post-transition economies, listed companies in their respective stock exchanges are in most cases on early stages of internationalization 


\section{Sport as a vehicle for implementing CSR}

(Radło and Ciesielska, 2015; Wilinski, 2012). This fact can potentially draw interesting comparisons between firms listed in western economies (e.g., FTSE-100). Second, both countries hosted two major sporting events: Poland (together with Ukraine) organised the 2012 UEFA European Football Championship, while Russia the 2018 FIFA World Cup. Research has empirically evidenced that events (including sport-focused ones) within communities and nations affect firms in the context of corporate philanthropy (Tilcsik and Marquis, 2013). As such, both countries offer the ideal setting to examine whether this is actually the case. We analysed annual reports and CSR reports. Firms often report only general information in their annual reports, while the CSR reports included all socially responsible initiatives undertaken by these firms in a more detailed and illustrative fashion (Bason and Anagnostopoulos, 2015).

In November and December 2018, we carried out a search of the official websites of firms listed on the Moscow Stock Exchange (MSE) and the Warsaw Stock Exchange (WSE). The purpose of this search was to locate the two types of documents over the previous five reporting years (2013 to 2017 inclusive). In total, 1,317 documents were content analysed, 442 from WSE firms and 875 from MSE firms (see Table 1).

Table 1 Number of each type of documents available on the official web site for each year of the MSE and WSE listed firms

\begin{tabular}{lrrrrrrrrrrrrr}
\hline & \multicolumn{2}{c}{2013} & \multicolumn{2}{c}{2014} & \multicolumn{2}{c}{2015} & \multicolumn{2}{c}{2016} & \multicolumn{2}{c}{2017} & \multicolumn{2}{c}{ Total } \\
\hline & WSE & MSE & WSE & MSE & WSE & MSE & WSE & MSE & WSE & MSE & WSE & MSE \\
Annual reports & 66 & 124 & 66 & 134 & 67 & 144 & 67 & 140 & 70 & 137 & 336 & 679 \\
CSR reports & 14 & 37 & 17 & 38 & 19 & 39 & 23 & 38 & 33 & 44 & 106 & 196 \\
Total & 80 & 161 & 83 & 172 & 86 & 183 & 90 & 178 & 103 & 181 & 442 & 875 \\
\hline \hline
\end{tabular}

In the first instance, both types of documents were extracted from the official websites of all 461 and 538 firms listed on the WSE and MSE, respectively. All reports were then analysed manually using the search function within Adobe Reader (searching for words like "sport", "athletes", etc.). Two trained research assistants identified the page number with the reference of the CSR-through-sport initiative while highlighting the text in the PDF document. We counted the frequency of key terms rather than the extent to which these concepts were discussed.

The analysis followed a deductive approach. We drew on the initially inductively developed conceptual framework by Bason and Anagnostopoulos (2015) (see Figure 1). The "philanthropy" stream is defined as a "corporate citizen[ship] without seeking to generate or exploit any association with the cause" (Polonsky and Speed, 2001, p. 1363). The "sponsorship" stream goes beyond mere patronage or a philanthropic action; it represents a business transaction and concerns some clear (sponsorship) activations (O'Reilly and Lafrance Horning, 2013). Finally, the "personnel engagement" stream concerns socially responsible programmes that use sport either for the benefit of the workforce within the firm or via the workforce for the benefit of divergent stakeholder groups (Preuss et al., 2009).

Using this framework as a roadmap, we assigned CSR-through-sport initiatives under first-order themes before further positioning the identified initiative under the secondorder themes. In a number of cases, the CSR-through-sport programme fitted more than 


\section{Author}

one theme and was therefore recorded in each. In a 2014 case from WSE, for example, the PKO BP bank's runners competed with customers within the project Drużynowa Liga Biegowa PKO Banku Polskiego (Team Running League of PKO Bank Polski). The project was accompanied by a charity campaign through which the winning team had the chance to indicate the purpose for which the Foundation of PKO Bank Polski would give a donation amounting to PLN 60,000. Therefore, this programme was categorised under the "philanthropy" (and "financial donations") as well as under "personnel engagement" (“employees' sporting activity").

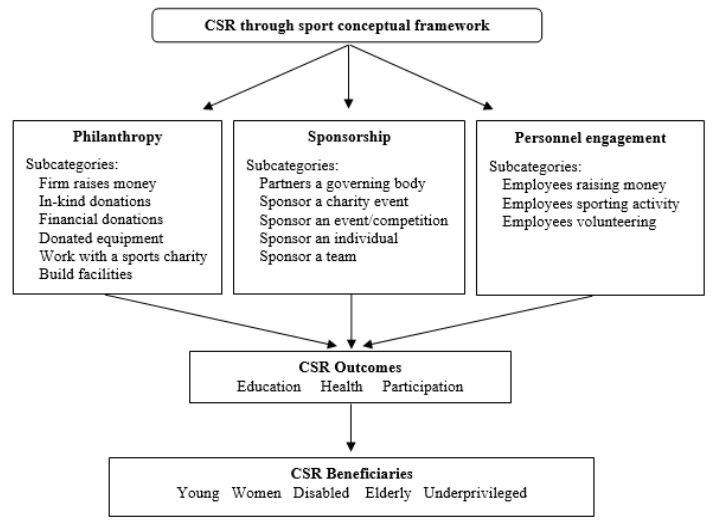

Based on Bason and Anagnostopoulos (2015)

In this deductive approach, the two research assistants who served as the initial coders were comprehensively briefed on the themes and sub-themes of the adopted framework (i.e., the codebook). Subsequently, a sample of 100 reports (50 annual and 50 CSR) was cross-checked by the first and third authors. Any CSR-through-sport programmes that were not felt to fit one of the categories were put aside; upon completion of this coding session, the authors discussed these programmes to resolve issues. Intercoder reliability, assessed using Cohen's $\kappa$, was 0.789 , which can be assessed as an acceptable level of agreement (Landis and Koch, 1977), thereby proving consistency of understanding and interpretation. Table 2 offers some illustrative examples of how coding was carried out and how data were grouped under first- and second-order categories.

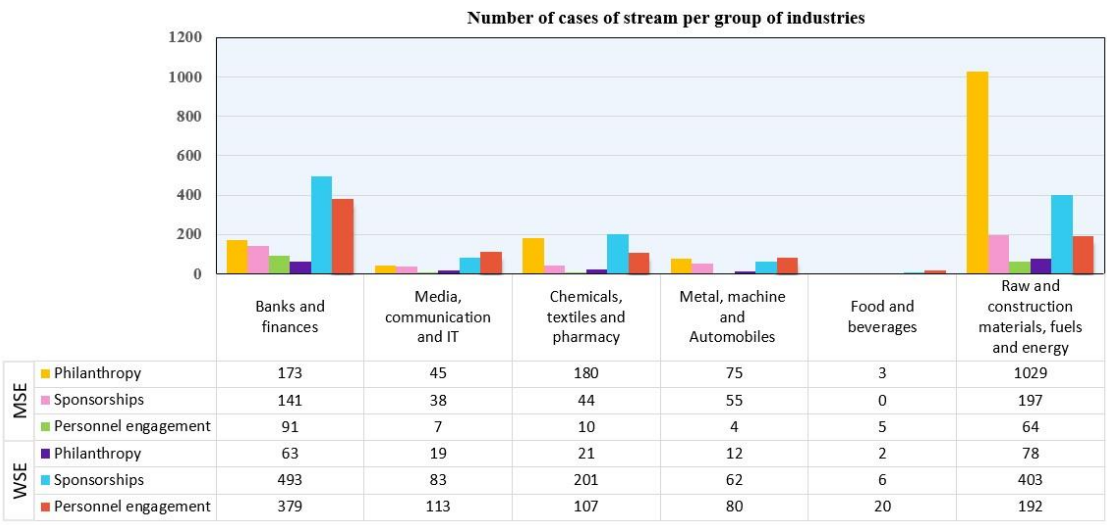


Sport as a vehicle for implementing CSR 
$2^{\text {nd }}$ order

n

Illustrative data

\begin{tabular}{|c|c|c|c|c|c|}
\hline & & WSE & MSE & WSE & MSE \\
\hline \multirow[t]{3}{*}{ Philanthropy } & $\begin{array}{l}\text { Firm raises } \\
\text { money }\end{array}$ & 99 & 2 & $\begin{array}{l}\text { Getin Noble Bank organized the "Fair Play Race". } \\
\text { The employees and friends of the bank were invited } \\
\text { to participate in the run. The event was charitable - } \\
\text { for every adult person who completed a } 5 \mathrm{~km} \text { race } \\
\text { in no more than } 50 \text { minutes, the Management Board } \\
\text { of Getin Noble Bank donated PLN } 15 \text { for } \\
\text { rehabilitation support to the Bank's employee who } \\
\text { underwent surgery to remove the spinal cord tumor } \\
\text { (2013) }\end{array}$ & $\begin{array}{l}\text { JSCB Agropromcredit Bank held a "Happy } \\
\text { Children" charitable event for the International } \\
\text { Children's Day were the money raised by the bank } \\
\text { employees within the framework of this event was } \\
\text { given to } 10 \text { sponsored childcare facilities }(2015)\end{array}$ \\
\hline & $\begin{array}{l}\text { In-kind } \\
\text { donations }\end{array}$ & 34 & 23 & $\begin{array}{l}\text { Stalprodukt covered the Bochnia team's departure } \\
\text { to Białystok to take part in the finals of the Polish } \\
\text { Youth Futsal Championships (2015) }\end{array}$ & $\begin{array}{l}\text { JSCB Agropromcredit Banck organised sports } \\
\text { events to raise money that was donated thorough in- } \\
\text { kind donations including personal hygiene } \\
\text { products, clothes, sports equipment, stationery, } \\
\text { educational toys, items for creativity, and other } \\
\text { items the children especially needed. (2017) }\end{array}$ \\
\hline & $\begin{array}{l}\text { Financial } \\
\text { donations }\end{array}$ & 91 & 388 & $\begin{array}{l}\text { Active, healthy and sporting foundation "Ray of } \\
\text { Joy" received from ING Bank Śląski PLN 12,000 } \\
\text { for a series of sports activities for children (2017) }\end{array}$ & $\begin{array}{l}\text { NLMK donated funds to sports clubs and athletes } \\
\text { that were allocated for the maintenance of sports } \\
\text { facilities and buildings (stadiums, sports complexes, } \\
\text { sports halls) and the purchase of sports equipment } \\
\text { (2014) }\end{array}$ \\
\hline
\end{tabular}

Copyright (C 2020 Inderscience Enterprises Ltd. 
Donated

equipment

Work with a

sports charity

Built

facilities

Sponsorships Partners a

governing

body
27 Lotos SA company funded over 800 pieces of ski equipment for the most talented jumpers during the project "We are looking for the Champion's Successors" (2013)

4 GK Comarch SA set up charitable project "Summer in a canoe"' in cooperation with the Zalew Jerzykowo School Sports Club for children and young people from rural areas (2017)

1061 FFiL Śnieżka SA within the "Colorful Playgrounds" project has been creating the conditions for active leisure time for the youngest. For example, a new full-size professional school playground was built at the Primary School in Pearls (2013)

5 Energa Sailing is Poland's largest complex program of support and promotion of sailing carried out in cooperation with the Polish Sailing Association and under the honorary patronage of the Minister of Sport and Tourism (2014)
Belarusbank purchased street and sports equipment for the educational and sports institution "Senno Specialized School for Children and Youth of Olympic Reserve" (2016)

Belarusbank support a non-profit social charity sports club "Wings of Angels" (2017)

Gazprom PJSC constructed several sport facilities. E.g., branches of the Avangard Hockey Academy; the sports and recreational complex Polyarny; the sports complex Yamal Arena (2017)

Belarusbank has made collaborations through sponsorship with different sport governing bodies like the Belarusian Federations of sports like hockey, sailing, freestyle or table tennis (2015) 
Author

Sponsor a

365

charity event

Sponsor an

event/

competition

Sponsor an

individual

Sponsor a

team

$\begin{array}{ll}\text { Personnel } & \begin{array}{l}\text { Employees } \\ \text { engagement } \\ \text { raising } \\ \text { money }\end{array}\end{array}$

27 PZU organised 35 charity running encouraging people to run a million miles to raise money for charity (2015)

344 Enea was an active sponsor of such events and sports initiatives as: Enea Challenge Poznan and a series of triathlon competitions Enea Tri Tour; Herbalife Ironman 70.3 Gdynia; EneaMini Cup football game for children and others (2015)

7 PGE Polska Grupa Energetyczna sponsored Victor Borsuk. The first kitesurfer in Poland who floats on the reservoir of Porąbka-Zar power plant belonging to PGE instead of a traditional water reservoir and won Góra Żar (2015)

105 Grupa Azoty annually sponsored the best volleyball teams in Poland ZAKSA Kędzierzyn-Koźle (men) and Chemik Police (women) to promote and develop this discipline among Poles (2016)

6 Alior Bank was represented by two teams of employees during charity project of Kompania Wrażeń within the Bator Tabor Polska Foundation. The collected money was spent on holiday trips for ill children (2013)

JSCB Agropromcredit Bank sponsored several events in one year, focused on support and populariza-tion of hockey (2015)

BNP Paribas is an active partner in tennis, participating as a sponsor of events like the Davis Cup (2015)

NLMK in collaboration with the Lipetsky Metallurg Sports Club, supported the training of 250 young sportsmen at the Lipetsky Metallurg Sports Club's trap-shooting range (2013)

During the "II Summer Games of Veterans of Sport" PJSC Asian - Pacific Bank was the official sponsor of the team of veterans (2013)

OJSC Nevinnomyssky Azot employees organised a sports-based team building event, which in turn raised funds for local children's charities. (2013) 
Sport as a vehicle for implementing CSR

Employees $\quad 767$

sporting

activity

Employees

volunteering
164 During the annual "Bicycle Breakfast" event organised by GK Comarch, employees who came to work by bicycle on that day received a healthy snack (2016)

Alrosa employees regularly engaged in sports activities from the subdivisions located in Mirny, Udachny and Aikhal, amounted to 7,500 persons (2015)

12 Over 150 of Amrest' employee volunteers were engaged in local project (including playing sports with children) within Stowarzyszenie SIEMACHA (SIEMACHA Society), an NGO based in Kraków. (2017)

Credit Bank of Moscow employees took an active part in team football, basketball and volleyball tournaments and also attended external and internal tournaments as volunteers (2015) 
As a final methodological point, the present study analysed cases from listed firms that reported at least one CSR-through-sport programme. Forty out of the 538 in the MSE case ( 7.43 per cent) met this criterion, and 70 out of 461 at the WSE case (15.18 per cent). The research team then classified/grouped these firms partly as per the industry in which they appear in their respective stock exchanges. The final categorisation includes a "big six" group of industries (see Table 3).

Table 3 Number of MSE and WSE firms with at least 1 CSR through sport initiative reported by groups of industries

\begin{tabular}{ccccccc}
\hline \multicolumn{7}{c}{ Industries Groups } \\
& $\begin{array}{c}\text { Banks \& } \\
\text { Finances }\end{array}$ & $\begin{array}{c}\text { Media, } \\
\text { Communication } \\
\& \text { IT }\end{array}$ & $\begin{array}{c}\text { Chemicals, } \\
\text { Textiles \& } \\
\text { Pharmacy }\end{array}$ & $\begin{array}{c}\text { Metal, } \\
\text { Machines \& } \\
\text { Automobiles }\end{array}$ & $\begin{array}{c}\text { Food \& } \\
\text { Beverages }\end{array}$ & $\begin{array}{c}\text { Raw and } \\
\text { Construction } \\
\text { Materials, } \\
\text { Fuels \& } \\
\text { Energy }\end{array}$ \\
MSE firms & 26 & 2 & 4 & 1 & 1 & 6 \\
WSE firms & 19 & 10 & 11 & 12 & 3 & 15 \\
Total & 45 & 12 & 15 & 13 & 4 & 21 \\
\hline \hline
\end{tabular}

\section{Results and discussion}

This section reports the findings of the present study and offers possible explanations behind certain trends. This study took into account the likelihood that the increased CSRthrough-sport cases reported in Bason and Anagnostopoulos' (2015) study was due to increased CSR reporting (in general). In the present study, whatever trends are mentioned "control" for this variance. That is, in the WSE case there has been a 28.75 per cent increase on CSR reporting, but a 78.35 per cent increase on the reported cases that have had sport at their core. As for the MSE, despite the 12.42 per cent increase on CSR reporting by the examined firms over the studied period, we saw a decrease $(-3.82$ per cent) of those CSR programmes that centred on sport.

\subsection{Philanthropy, sponsorship and personnel engagement streams}

A total of 2,501 CSR-through-sport initiatives were reported over the five-year period studied in the WSE case and 2,175 in the MSE case. Figure 2 shows an overview of the evolution of the number of CSR-through-sport in both cases, categorised under the philanthropy, sponsorships and personnel engagement streams. In the WSE case, the number of revealed cases increased from 328 in 2013 to 585 in 2017. Furthermore, the three streams experienced growth between 2013 and 2017, especially in the sponsorships and personnel engagement streams. The increased number of sponsorships until 2016 could perhaps be explained by the 2016 Summer Olympic Games in Rio de Janeiro; just after the Games ended, the number of CSR-through-sport sponsorships decreased. Regarding the MSE case, the sponsorships and personnel engagement streams presented 


\section{Sport as a vehicle for implementing CSR}

silent growth over the years studied. On the other hand, the stream with more cases with difference is philanthropy, although there was a clear fall from 2013 to 2015, followed by growth between 2015 and 2017. This evolution can be understood due to two major events held in Russia, where the government encouraged large corporations that traditionally experienced a lack of social trust (Kuznetsov and Kuznetsova, 2008) to carry out philanthropic actions to legitimise their activity, helping to build the infrastructure for the Sochi Winter Olympic and Paralympic Games in 2014 and the FIFA World Cup in 2018. Consequently, when the dates of the Sochi Winter Olympic and Paralympic Games were reached, the philanthropy stream went down, only to recover and grow again as the 2018 FIFA World Cup in Russia approached.

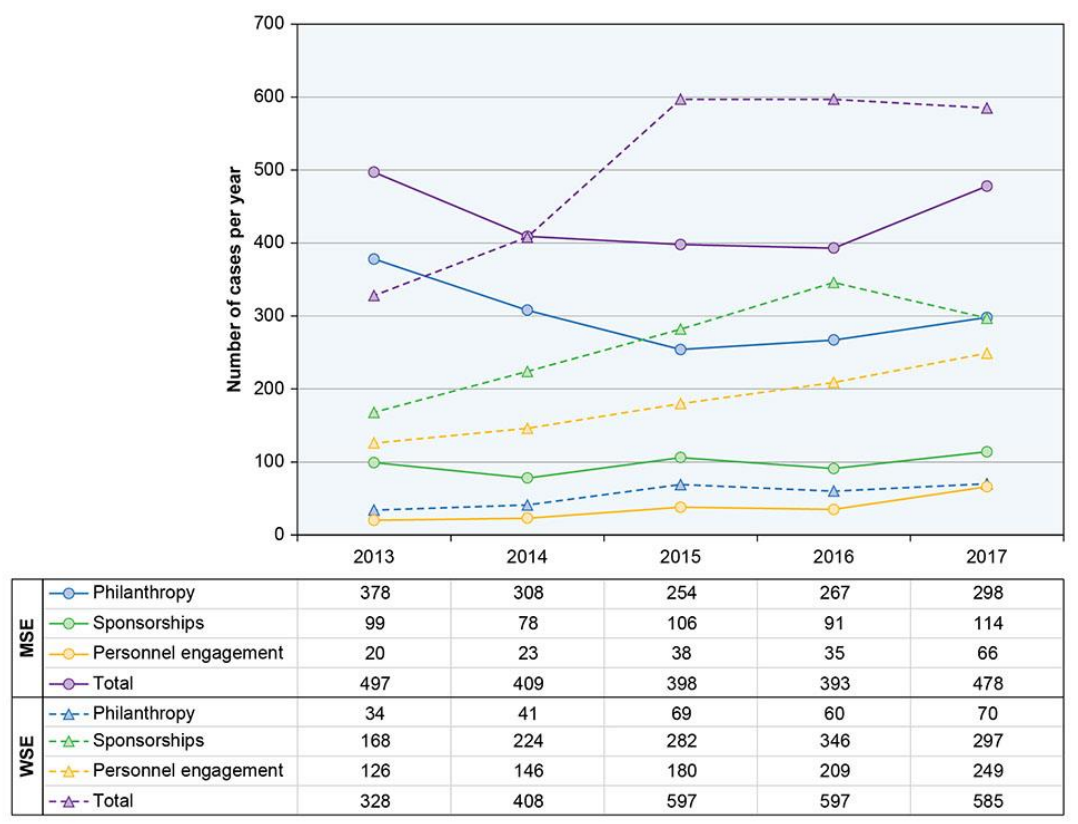

Focusing on the philanthropic stream, 274 instances (which represent the 10.95 per cent) were reported in the WSE case, while 1505 philanthropic initiatives (69.19 per cent) were reported in the MSE case. This represents a significant contrast in the two cases studied, as the philanthropic stream is the lowest of the WSE case, but the highest in the MSE. This implies two different ways of conceiving and managing the CSR thorough sport initiatives. The WSE results are similar to those of Bason and Anagnostopoulos (2015), where the philanthropy stream also had the smallest number of firms involved. On the other hand, the high weight of the philanthropy stream in the MSE is probably a response to the use of these CSR-through-sport instances as a "strategic philanthropy" (Bruch and Walter, 2005) seeking to close the legitimacy gaps and the lack of social trust towards large Russian companies (Kuznetsov and Kuznetsova, 2008), which many Russians perceive as non-transparent and corrupt (Filippov, 2012).

We now turn our attention to the six sub-streams of the philanthropy stream (see Figure 3). In the WSE case, "raises money" was the highest sub-stream with 99 CSRthrough-sport initiatives reported. Companies mostly achieved this through organising 


\section{Author}

charity runs or competitions. For instance, in 2016, PZU supported 13 running events that were accompanied by the "Share a Kilometre" campaign, according to which the company paid PLN 10 for each kilometre run to a selected charitable organisation. Participants ran more than $15,810 \mathrm{~km}$, so 158,100 PLN was donated to 13 different organisations. As for the MSE case, the built facilities sub-stream was the most popular, with 1061 cases. The Gazprom Group was closely involved in this sub-stream, contributing to the building of sport facilities for the Sochi Winter Olympic and Paralympic Games in 2014. The second-most popular sub-stream, in both cases, has been the "financial donations"; however, in both cases it has been difficult to find concrete examples as many firms only reported the fact that they donated money to sport teams, individuals or initiatives, without giving details about the nature of the donations. Some of them reported the "sport" area in the range of their donations. Finally, the rest of the philanthropy sub-streams present very low values in both cases, but especially in the MSE case.

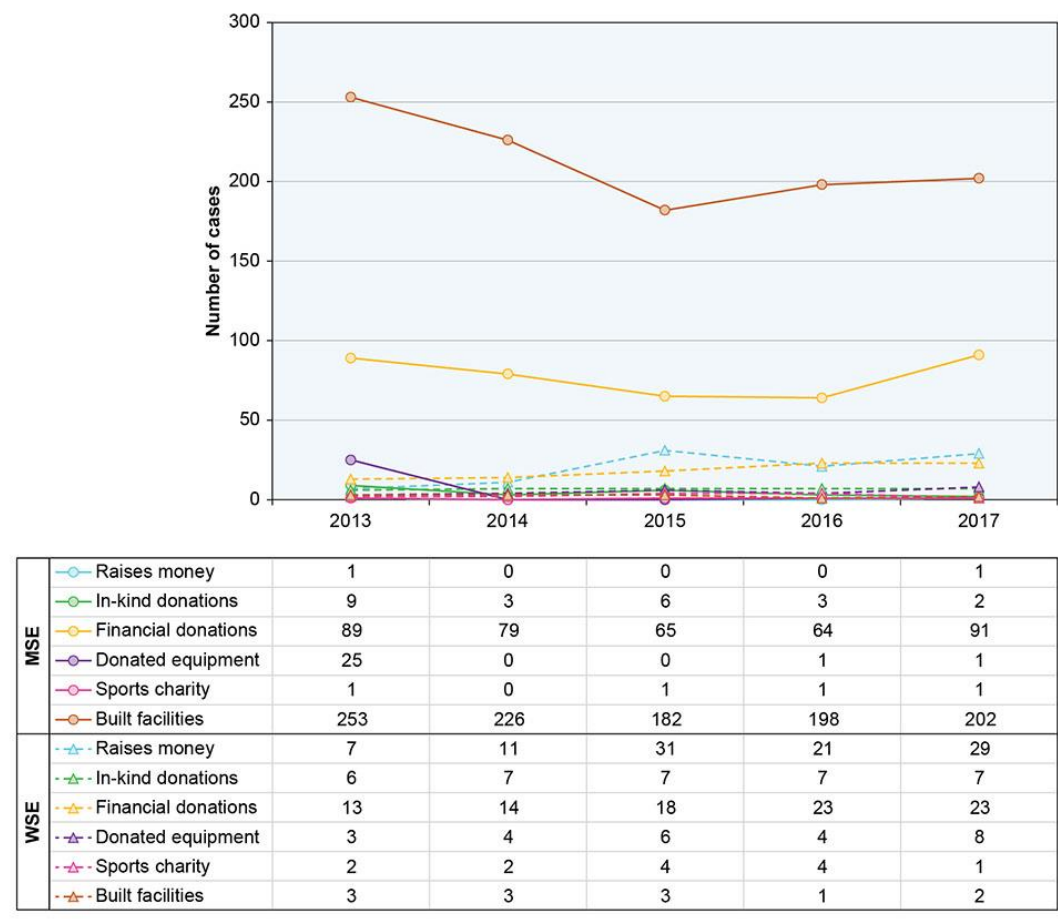

Concerning the sponsorships stream, 1317 sponsor instances ( 52.65 per cent) were reported in the WSE case, compared to 488 in the MSE case (22.43 per cent). In the WSE case, all sub-streams demonstrate a growing trend over the period, except sponsoring an event/competition and sponsoring a charity event, which fell noticeably after 2016 (Figure 4). Even with the decline between 2016 and 2017, the most popular sub-stream was sponsoring an event or competition, with 552 of 1317 reported cases being in the of "sponsorships" stream. This can be explained by major sporting events, such as the 2016 EHF European Men's Handball Championship in Poland, and the 2016 Summer Olympics in Rio de Janeiro. Companies wanted to be associated with events and competitions in order to increase their brand awareness and enhance their reputation through sports-related CSR practices (Chen et al., 2008). As for the MSE case, similar to WSE, the sponsoring an event/competition was clearly the sub-stream that received more 


\section{Sport as a vehicle for implementing CSR}

CSR through sporting initiatives, with 334 cases out of 488 in the sponsorships stream. We could especially link the growth between 2016 and 2017 with the proximity of the organisation of the FIFA World Cup of football in 2018. As Dowling et al. (2013) indicated, "timing and context matters, with sport being inherently more attractive in the lead up to mega-events" (p. 288) and it is more probable that these partnerships happen, or at least are reported, if the company has its headquarters in the host country of the mega event (Bason and Anagnostopoulos, 2015). This is the situation with the MSE case, and the 2018 FIFA World Cup, with firms such as Gazprom making large football sponsorships during the studied period. Finally, the rest of the results of the "sponsorship" sub-streams in the MSE case do not show a growth trend but are instead relatively stable, with the exception of the sub-stream "sponsor a team", which dropped between 2015 and 2017.

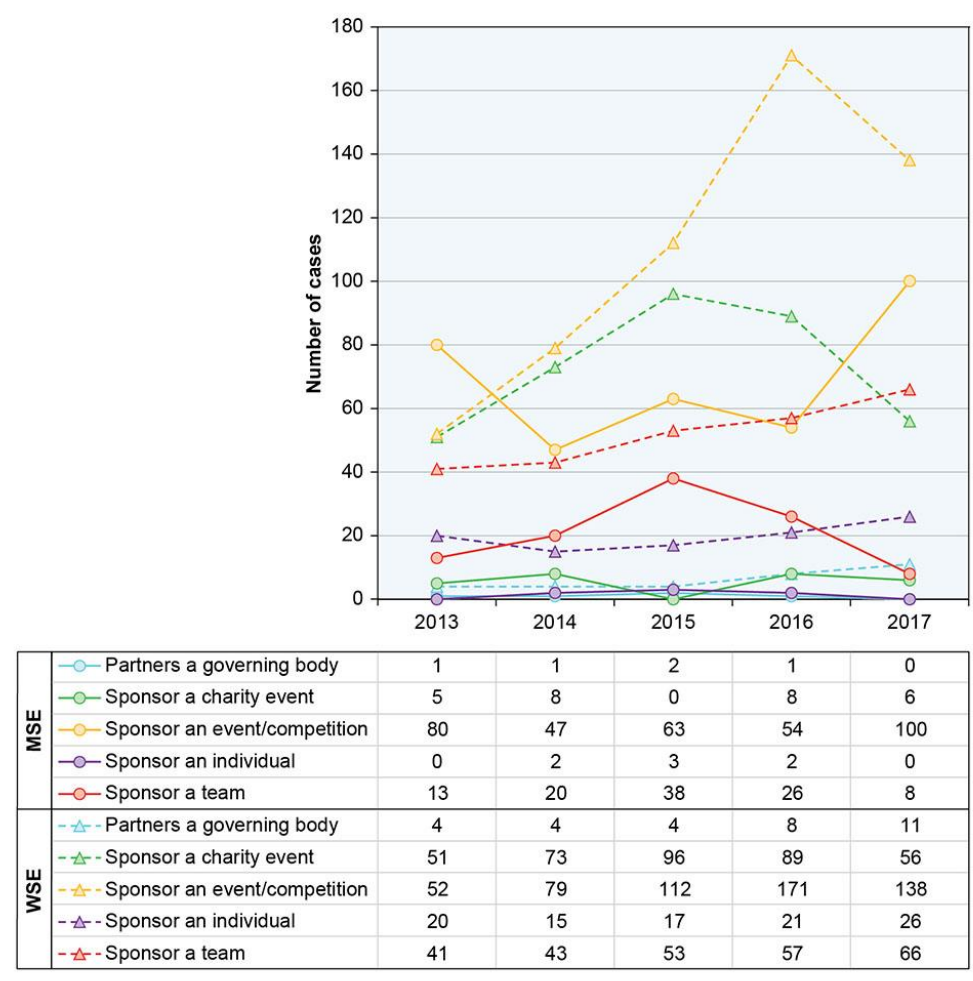

Regarding the personnel engagement stream, 910 instances (36.38 per cent) were reported in the WSE case, and 182 initiatives (8.36 per cent) in the MSE. In both cases, the employees' sporting activity sub-stream grew the most compared to the other two sub-streams (Figure 5). In the WSE case, the growth trend is constant between 2014 and 2017, while in the MSE case there is a big leap from 2016 to 2017. In both cases, the majority of the studied firms studied pushed this sub-stream with initiatives, giving their employees free access to various sporting facilities (gyms, sports grounds, ice rinks, courts, swimming pools) and opportunities to take part in various sport events and competitions organised by their firms and to improve their health condition. These results are not surprising since the literature argues that employee involvement in CSR actions is 


\section{Author}

strategically important. Glavas (2016) argued that an employee is perhaps the stakeholder who "wins" the most. Mirvis (2012) designated a set of reasons for firms to engage their employees, ranging from competitive advantages in recruiting process to more efficient human resource management. From the immediate financial side, Edmans (2011) showed a positive relationship between employee engagement and a company's stock price and revenue rise. Another aspect to highlight is that almost all of the firms studied (62 out of 70 in the WSE case and 37 out of 40 in the MSE case) were involved in personnel engagement stream. This element of CSR is associated with the direct staff engagement in efforts leading to community enhancement (Caligiuri et al., 2013) and also with indirect benefits for companies; for example, staff turnover, lower absenteeism, good workplaces, talent recruitment, etc. Sure enough, employee's involvement in worthwhile projects (such as cases from the "employees raising money" sub-stream) or programmes developing new skills (for example, cases from the employee volunteering sub-stream) are connected with benefiting different stakeholder groups (Morgeson et al., 2013).

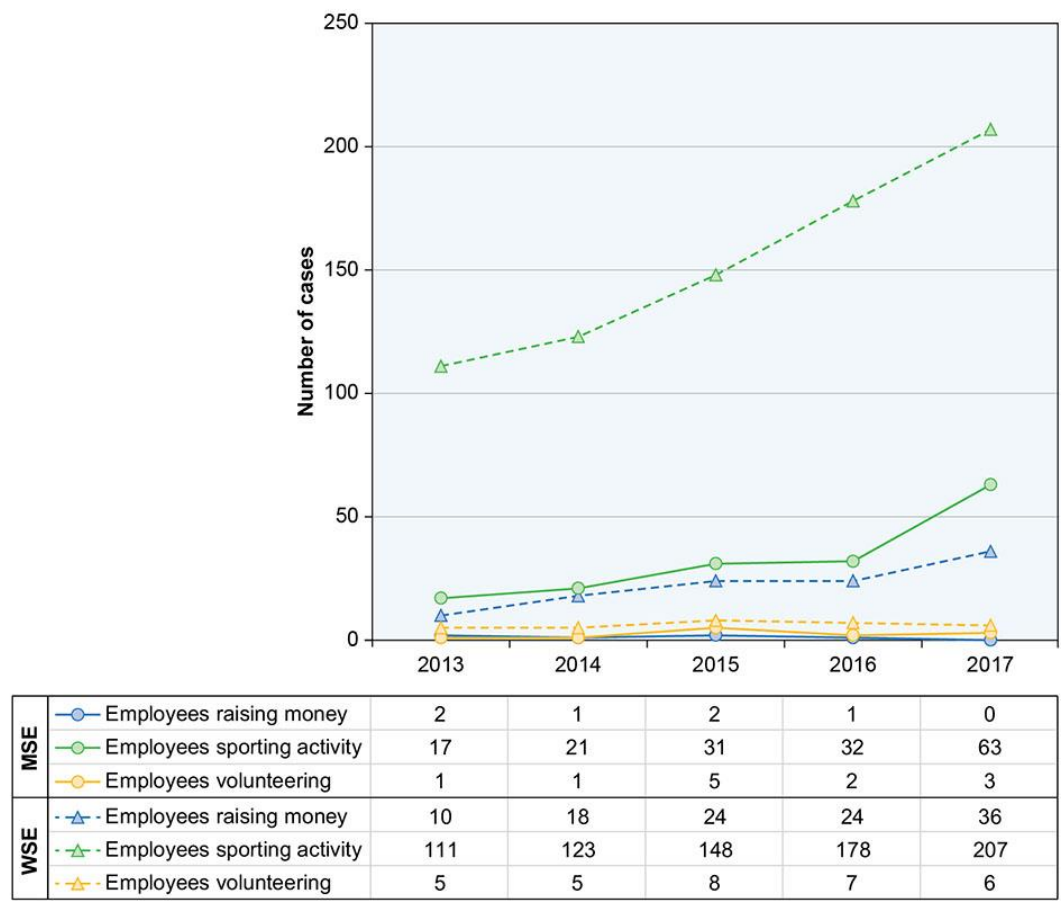

\subsection{Beneficiaries and Outcomes}

With regard to the type of beneficiaries of the CSR-through-sport initiatives of the two cases studied, we classified each of the reported CSR initiatives with one group of the five types of beneficiaries that Bason and Anagnostopoulos (2015) identified: young, elderly, women, disabled and under privileged. As depicted in Figure 6, in both cases, the "young" category is by far the main target of the CSR-through-sport initiatives of the companies studied. Typical examples involving youth and children were initiatives aiming to encourage young people to participate in sports activities. For instance, in the 


\section{Sport as a vehicle for implementing CSR}

WSE case, Orlen cooperates systematically with the Association of Children and Youth Sport, the organiser of "Athletics Thursdays", the largest sports event in Poland, held in 70 Polish cities and addressed to young people. On the other hand, it was identified that many companies' aim was benefiting youngsters through education. For example, one of the CSR initiatives of Apatit (MSC case) sought to promote education and a healthy lifestyle among children, developing youth sports and healthy lifestyles. In 2013, over 15,000 children participated in the programmes across six regional sport and educational centres. The results obtained in this stream are similar to those of Bason and Anagnostopoulos (2015). In the latter work, the disabled sub-stream also saw clear growth, which did not occur in the WSE and MSE cases, apart from a small growth trend between 2016 and 2017. On the other hand, the decrease experienced in the MSE case between 2014 and 2017 remains unclear, considering that Russia has experienced a context of major sporting events. It would be interesting to investigate further, through other methodological approaches, what may have happened in this regard. Finally, it is remarkable that there was no clear growth in the sub-stream of "women" given the current social repercussion of the feminist movement, with sport being one of the social spheres where the movement has had the greatest repercussions. This represents an area for more explanatory research.

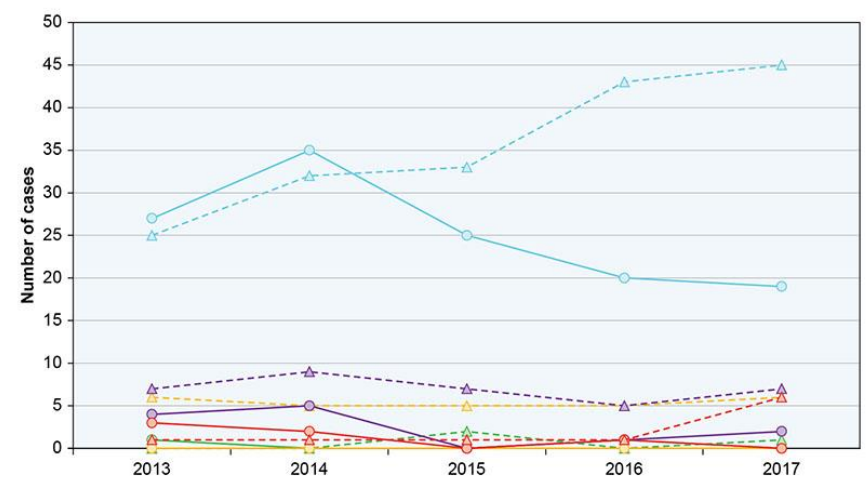

\begin{tabular}{|c|c|c|c|c|c|c|}
\hline \multirow{5}{*}{$\frac{\mathscr{D}_{2}}{\Sigma}$} & $-\infty$-Young & 27 & 35 & 25 & 20 & 19 \\
\hline & $-\circ$ Eldery & 1 & 0 & 0 & 1 & 0 \\
\hline & $-\infty$ Women & 0 & 0 & 0 & 0 & 0 \\
\hline & - -Disable & 4 & 5 & 0 & 1 & 2 \\
\hline & $-\infty$ - Under-privileged & 3 & 2 & 0 & 1 & 0 \\
\hline \multirow{5}{*}{ 岗 } & -4 Young & 25 & 32 & 33 & 43 & 45 \\
\hline & - $-\Delta$-Eldery & 0 & 0 & 2 & 0 & 1 \\
\hline & - Women & 6 & 5 & 5 & 5 & 6 \\
\hline & $-\triangleleft$-Disable & 7 & 9 & 7 & 5 & 7 \\
\hline & $-\Delta-$ Under-privileged & 1 & 1 & 1 & 1 & 6 \\
\hline
\end{tabular}

As for the "outcomes", in the WSE case, three sub-streams (education, health and "participation) outpaced growth, but on different scales (Figure 7). The most prevalent outcomes were focused on increasing participation. In the WSE case, 1032 CSR-throughsport initiatives led directly to participants taking part in a sporting event or sports activity. The second and third outcome sub-streams for WSE were education and health, with 80 and 51 CSR-through-sport initiatives reported. Regarding the MSE case, 415 initiatives had an increase in participation in sport as an outcome, with two growing tendencies over the five years studied. The "health" sub-stream is in second place with 


\section{Author}

178 instances, aiming directly to improve health. Many firms have reported such examples over the five years, having implemented multiple sports programmes and CSR initiatives in order to improve the physical health of the employees. The final, and least prominent, sub-stream is education, with 81 cases, alternating two small up and down tendencies between the years studied. Even indirectly, the outcome of the participation sub-stream implies an improvement in health on the part of the beneficiaries of these actions; however, due to the aims of this research, only those actions that directly mention health benefits have been included in this category.

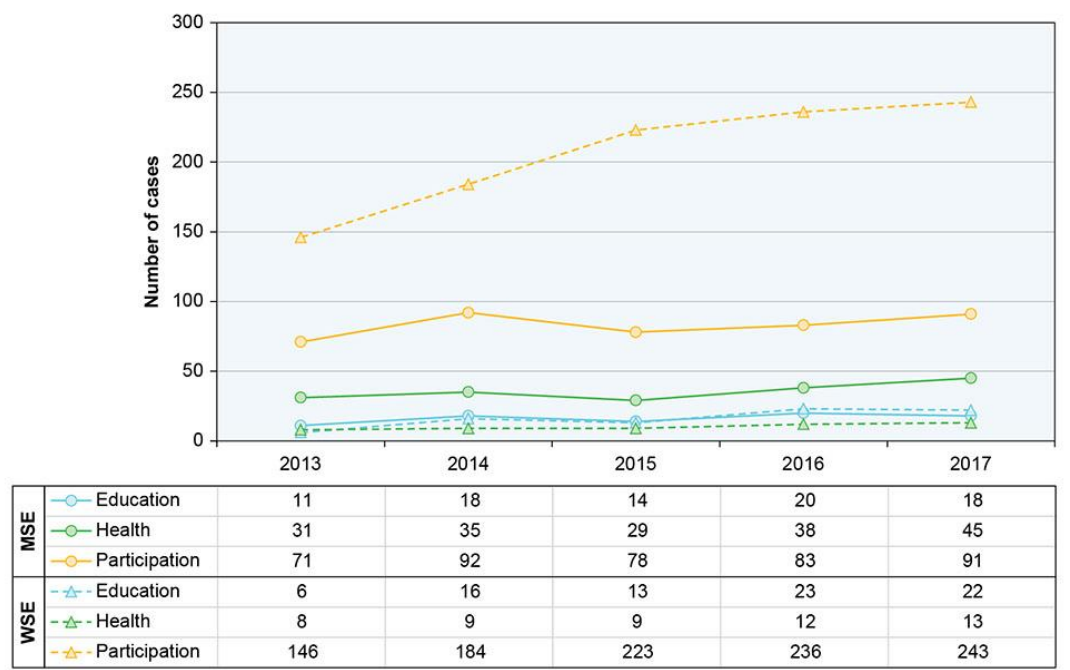

\subsection{Industry Groups}

Last but not least, focusing on the six categorised industry groups - Banks and Finances; Media, Communication and IT; Chemicals, Textiles and Pharmacy; Metal, Machine and Automobiles; Food and Beverages; and Raw and Construction Materials, Fuels and Energy -differences are observed between the two cases studied. On one hand, in the WSE case, the Banks and Finances group presented a higher number of CSRthrough-sport initiatives with 935 reported cases, especially among the sponsorship stream (493 cases). The next group of industries that stands out in the WSE case is Raw and Construction Materials, Fuels and Energy, with 673 cases, again being associated with the sponsorship stream that more initiatives receive (403 cases). In the MSE case, this clearly highlights the dominance of the group Raw and Construction Materials, Fuels and Energy, with 1,290 cases, where the philanthropy stream had the most cases reported ( 1,029 cases). This is understandable given that Russia is a country with many natural resources controlled by large corporations. As mentioned, Russian companies tend to use CSR to legitimate their practices, with firms like Gazprom (gas), Rosneft (petrol) and SUEK (coal) making large investments through philanthropically actions. For example, Gazprom took over part of the responsibility for the preparations for a major and global sporting event such as the Sochi 2014 Winter Olympics and Paralympic Games. Beyond philanthropic actions, the next group is Banks and Finances, with 405 reported cases, again led by the "philanthropy" stream (173 cases). Finally, it should be noted that the "Food and Beverages" group, both in WSE and MSE cases, is, according to the results 


\section{Sport as a vehicle for implementing CSR}

reported, the group least involved in CSR-through-sports initiatives. This is an interesting potential avenue for future research because this industry has traditionally been closely linked to sport. Specific studies in this regard are necessary in order to determine whether such actions occur but are not reported, or whether they do not occur in the sports context, as is the case of other types of industries.

\section{Conclusions and Implications}

The purpose of this study was to empirically assess whether there is any truth to increased claims that sport constitutes an ideal vehicle for deploying CSR. We conducted this assessment by drawing on Bason and Anagnostopoulos' (2015) conceptual framework to categorise all reported CSR initiatives that have had sport at their core in the firms listed on the Warsaw and Moscow Stock Exchanges. Thus, the present paper offers a descriptive account highlighting that corporate international firms (at least in certain industries) seem to respond to mimetic and normative pressures by considering sport as a 'recipe' for best practices.

From an institutional isomorphism perspective, the social environment pushes sport as a powerful social manifestation with great influences in different spheres (such as economy, politics, and sociology), pressuring firms to become more similar regarding the perception of sport as an appealing platform to enhance and consolidate their social legitimacy. This can be seen, for example, in how the 'personnel engagement' stream is the only one that shows growth, with no decrease, over the five years studied in both cases. Sport is becoming increasingly socially accepted and popular, which calls for firms to encourage their employees to practice CSR through sport initiatives that encourage or support it.

Given that CSR for firms is "one of the social pressures they have absorbed" (The Economist, 2008, p. 8), one should expect that sport will continue playing a key role in the formulation and implementation of initiatives that strive to create shared value (Porter and Kramer, 2011). As such, CSR managers within international firms should shift their attention to strategic and professional forms of CSR through sport, while sports administrators should start targeting the specific industries that seem most likely to consider sport for the deployment of their CSR agendas. Moreover, although the young generations continue to be the main target group for firms' CSR programmes, there may also be an opportunity to shift attention to women or elderly citizens, who could have a higher impact on the firms' bottom lines in the short-term.

The study has certain limitations. First, although an approach to control between level of reporting and sport-based CSR initiatives was disclosed, it is challenging to verify which of those programmes have actually been implemented. In other words, the fact that CSR disclosures are self-reported documents raises suspicion about whether every detail provided by firms reflects the real facts (Papacharalampous et al., 2019). For example, in the sub-stream financial donations, it was difficult to observe concrete examples because many firms reported only the fact that they had donated money to sport teams or individuals, without giving details about the nature of the donations. In this sense, promoting studies that use different methodologies could be very useful for complementing or deepening the motives or causes behind the results obtained in the current study. Second, as in the study of Bason and Anagnostopoulos (2015), the current work was delimited to categorising programmes as per the adopted conceptual 
Author

framework, thereby avoiding an examination of concrete relationships amongst the three streams, beneficiaries and/or outcomes.

Overall, however, it is promising that firms outside sport are increasingly embracing sport for the deployment of their CSR agendas. It is hoped that the results reported herewith will stimulate additional - and more explanatory in nature - research, which, in turn, will display how powerful the mechanism of sport can be in creating shared value.

\section{Acknowledgements}

Christos Anagnostopoulos and Jolanta Zysko wish to thank Mariia Servuli and Valeriia Hubska who assisted on the data collection process. Samuel López-Carril wishes to acknowledge the support he received through a pre-doctoral contract "FPU15/05670" granted by the Spanish Ministry of Science, Innovation and Universities.

\section{References}

Aguinis, H. and Glavas, A. (2012) 'What We Know and Don't Know About Corporate Social Responsibility: A Review and Research Agenda', Journal of Management, Vol. 38, No. 4, pp. 932-968

Ahonen, A. and Persson, H.T.R. (2020) 'Social Entrepreneurship and Corporate Social Responsibility in Team Sport Clubs: Two Cases from Sweden and Finland', in Ratten, V. (Ed), Sport Entrepreneurship and Public Policy: Building a New Approach to Policy-Making for Sport, Springer, Cham, pp. 7-21.

Amaeshi, K., Adegbite, E., Ogbechie, C., Idemudia, U., Kan, K.A.S., Issa, M. and Anakwue, O.I.J. (2016) 'Corporate Social Responsibility in SMEs: A Shift from Philanthropy to Institutional Works?’, Journal of Business Ethics, Vol. 138, No. 2, pp.385-400.

Anagnostopoulos, C., Byers, T., and Kolyperas, D. (2017). 'Understanding strategic decision-making through a multi-paradigm perspective: The case of charitable foundations in English football', Sport, Business and Management: An International Journal, Vol. 7, No. 1, pp. 2-20.

Baier-Fuentes, H., Hormiga, E., Miravitlles, P. and Blanco-Mesa, F. (2019) 'International entrepreneurship: A critical review of the research field', European Journal of International Management, Vol. 13, No. 3, pp. 381-412.

Bason, T. and Anagnostopoulos, C. (2015) 'Corporate social responsibility through sport: a longitudinal study of the FTSE100 companies', Sport, Business and Management: An International Journal, Vol. 5, No. 3, pp.218-241.

Batty, R.J., Cuskelly, G. and Toohey, K. (2016) 'Community Sport Events and CSR Sponsorship: Examining the Impacts of a Public Health Agenda', Journal of Sport and Social Issues, Vol. 40, No. 6, pp.545-564.

Beddewela, E. and Fairbrass, J. (2016) 'Seeking Legitimacy Through CSR: Institutional Pressures and Corporate Responses of Multinationals in Sri Lanka', Journal of Business Ethics, Vol. 136, No. 3, pp.503-522.

Benn, S., Todd, L. R. and Pendleton, J. (2010) 'Public Relations Leadership in Corporate Social Responsibility', Journal of Business Ethics, Vol. 96, No. 3, pp.403-423. 
Sport as a vehicle for implementing CSR

Berg, N., Holtbrügge, D., Egri, C.P., Furrer, O., Sinding, K. and Dögl, C. (2018) 'Stakeholder pressures, CSR practices, and business outcomes in Denmark, Germany and the Netherlands', European Journal of International Management, Vol. 12, No. 4, pp.472-500.

Breitbarth, T., Walzel, S., Anagnostopoulos, C. and van Eekeren, F. (2015) 'Corporate social responsibility and governance in sport: 'Oh, the things you can find, if you don't stay behind!’, Corporate Governance, Vol. 15, No. 2, pp.254-273.

Bruch, H. and Walter, F. (2005) 'The keys to rethinking corporate philanthropy', MIT Sloan Management Review, Vol. 47, No. 1, pp.49-55.

Caligiuri, P., Mencin, A and Jiang, K. (2013) 'Win-win-win: the influence of company sponsored volunteerism programs on employees, NGOs, and business units', Personnel Psychology, Vol. 66, No. 4, pp.825-860.

Campbell, J.L. (2007) 'Why Would Corporations Behave in Socially Responsible Ways? An Institutional Theory of Corporate Social Responsibility', Academy of Management Review, Vol. 32, No. 3, pp.946-967.

Carrasco-Monteagudo, I. and Buendía-Martínez, I. (2013) 'Corporate social responsibility: A crossroad between changing values, innovation and internationalisation', European Journal of International Management, Vol. 7, No. 3, pp.295-314.

Chalkasra, L.S.P.S., Rivera, J.P.R. and Basuil, D.A.T. (2019) 'A Review of Theoretical Perspectives on CSR Among Family Enterprises', Vision, Vol. 23, No. 3, pp.225-233.

Chen, J.C., Patten, D.M. and Roberts, R.W. (2008) 'Corporate charitable contributions: a corporate social performance or legitimacy strategy?', Journal of Business Ethics, Vol. 82, No. 1, pp.131-144.

Cordeiro, J.J. and Tewari, M. (2015) 'Firm Characteristics, Industry Context, and Investor Reactions to Environmental CSR: A Stakeholder Theory Approach', Journal of Business Ethics, Vol. 130, No. 4, pp.833-849.

Council of Europe (1992) European Sports Charter. Available online at: https://rm.coe.int/16804c9dbb (Accessed 18 November 2019).

Crespo, N.F. and Aurélio, D. (2020) 'Between domestic and international new ventures: The relevance of entrepreneurs' and firms' characteristics', European Journal of International Management, Vol. 14, No. 1, pp. 28-54.

DiMaggio, P.J. and Powell, W.W. (1983) 'The iron cage revisited: institutional isomorphism and collective rationality in organizational fields', American Sociological Review, Vol. 48, No. 2, pp.147-161.

Djaballah, M., Hautbois, C. and Desbordes, M. (2017) 'Sponsors' CSR strategies in sport: A sensemaking approach of corporations established in France', Sport Management Review, Vol. 20, No. 2, pp.211-225.

Dowling, M., Robinson, L. and Washington, M. (2013) 'Taking advantage of the London 2012 Olympic games: corporate social responsibility through sport partnerships', European Sport Management Quarterly, Vol. 13, No. 3, pp.269292. 
Author

Du, S. and Vieira, E.T. Jr. (2012) 'Striving for legitimacy through corporate social responsibility: Insights from oil companies', Journal of Business Ethics, Vol. 110, No. 4, pp.413-427.

Edmans, A. (2011) 'Does the stock market fully value intangibles? Employee satisfaction and equity prices', Journal of Financial Economics, Vol. 101, No. 3, pp.621640.

Eissa, M.A. and Refai, H.A. (2018) 'Mega-sports events and stock market returns: The case of the 2022 World Cup', Event Management, Vol. 22, No. 3, pp. 379-388.

Ertuna, B. and Tükel, A. (2010) 'Traditional versus international influences: CSR disclosures in Turkey', European Journal of International Management, Vol. 4, No. 3, pp.273-289.

Filippov, S. (2012) 'Emerging Russian multinational companies: Managerial and corporate challenges', European Journal of International Management, Vol. 6, No. 3, pp.323-341.

Glavas, A. (2016) 'Corporate Social Responsibility and Employee Engagement: Enabling Employees to Employ More of Their Whole Selves at Work', Frontiers in Psycholgy, Vol. 7, 796.

Godfrey, C., Hatch, W. and Hansen, M. (2010) 'Toward a general theory of CSRs: The roles of beneficence, profitability, insurance, and industry heterogeneity', Business \& Society, Vol. 49, No. 2, pp.31-344.

Godfrey, P. (2009) 'Corporate social responsibility in sport: an overview and key issues', Journal of Sport Management, Vol. 23 No. 6, pp.698-716.

Gray, R., Kouhy, R. and Lavers, S. (1995) 'Methodological themes constructing a research database of social and environmental reporting by UK companies', Accounting, Auditing \& Accountability Journal, Vol. 8, No. 2, pp.78-101.

Gray, R., Kouhy, R. and Lavers, S. (1995) 'Methodological themes constructing a research database of social and environmental reporting by UK companies', Accounting, Auditing \& Accountability Journal, Vol. 8, No. 2, pp.78-101.

Greenwood, R., Oliver, C., Sahlin, K. and Suddaby, R. (Eds.). (2008) Sage Handbook of Organizational Institutionalism. London, UK: Sage

Hayduk III, T. (2020) 'The Future for Sport Entrepreneurship', in Ratten, V. (Ed.), Sport Entrepreneurship and Public Policy: Building a New Approach to PolicyMaking for Sport, Springer, Cham, pp. 135-152.

Inoue, Y. and Kent, A. (2012) 'Investigating the role of corporate credibility in corporate social marketing: A case study of environmental initiatives by professional sport organizations', Sport Management Review, Vol. 15, No. 3, pp.330-344.

Kolyperas, D., Anagnostopoulos, C., Chadwick, S. and Sparks, L. (2016) 'Applying a communicating vessels framework to CSR value co-creation: Empirical evidence from professional team sport organizations', Journal of Sport Management, Vol. 30, No. 6, pp.702-719.

Kudlak, R. and Low, K.Y.J. (2015) 'Special issues dedicated to CSR and corporate sustainability: A review and commentary', Long Range Planning, Vol. 48, No. 3, pp.215-227. 
Sport as a vehicle for implementing CSR

Kuznetsov, A. and Kuznetsova, O. (2008) 'Gaining competitiveness through trust: the experience of Russia', European Journal of International Management, Vol. 2, No. 1, pp.22-38.

Kuznetsov, A. and Kuznetsova, O. (2010) 'The role of stakeholders in shaping managerial perceptions of CSR in Russia', European Journal of International Management, Vol. 4, No. 3, pp. 257-272.

Landis, J.R. and Koch, G.G. (1977) 'The measurement of observer agreement for categorical data', Biometrics, Vol. 33, No. 1, pp.159-174.

Levermore, R. (2010) 'CSR for Development Through Sport: examining its potential and limitations', Third World Quarterly, Vol. 31. No. 2, pp.223-241.

Levermore, R. (2011) 'Evaluating sport-for-development: approaches and critical issues', Progress in Development Studies, Vol. 11 No. 4, pp.339-353.

Malik, M. (2015) 'Value-Enhancing Capabilities of CSR: A Brief Review of Contemporary Literature', Journal of Business Ethics, Vol. 127, No. 2, pp.419438.

McDonald, S., Smith, A. and Westerbeek, H. (2009) 'Using sport and physical activity (PA) in corporate social responsibility programs: an analysis of indexed multinationals', in Rodríguez, P., Késenne, S. and Dietl, H. (Eds), Social Responsibility and Sustainability in Sports, Universidad de Oviedo, Oviedo, pp.111-134.

Milne, M.J. and Adler, R.W. (1999) 'Exploring the reliability of social and environmental disclosures content analysis', Accounting, Auditing \& Accountability Journal, Vol. 12, No. 2, pp.237-256.

Miragaia, D.A.M., Ferreira, J. and Ratten, V. (2017) 'Corporate social responsibility and social entrepreneurship: drivers of sports sponsorship policy’, International Journal of Sport Policy, Vol. 9, No. 4, pp. 613-623.

Mirvis, P. H. (2012) 'Employee Engagement and CSR: Transactional, Relational, and Developmental Approaches', California Management Review, Vol. 54, No. 4, pp.93-117.

Morgeson, F.P., Aguinis, H., Waldman, D. and Siegel, D. (2013) 'Extending corporate social responsibility research to the human resource management and organisational behavior domains: a look to the future', Personnel Psychology, Vol. 66, No. 4, pp.805-824

Morrow, S. (2012) 'Corporate social responsibility in sport', in Robinson, L., Chelladurai, P., Bodet, G. and Downward, P. (Eds.), Routledge Handbook of Sport Management, Routledge, Oxon, pp.101-115.

Muñoz, R.M., Sánchez de Pablo, J.D. and Peña, I. (2015) 'Linking corporate social responsibility and financial performance in Spanish firms', European Journal of International Management, Vol. 9, No. 3, pp.368-383.

Oh, W.-Y., Choi, K.J., Chang, Y.K. and Jeon, M.-K. (2019) 'MNEs' Corporate Social Responsibility: An Optimal Investment Decision Model', European Journal of International Management, Vol. 13, No. 3, pp. 307-327.

O'Reilly, N. and Lafrance Horning, D. (2013) 'Leveraging sponsorship: The activation ratio’, Sport Management Review, Vol. 16, No. 4, pp. 424-437. 3. 
Author

Papacharalampous, N., Papadimitriou, D. and Anagnostopoulos, C. (2019) "'Walking the talk" in times of recession: the case of corporate social responsibility in Greece', Journal of Global Responsibility, Vol. 10, No. 2, pp. 102-118.

Polonsky, M.J. and Speed, R. (2001) 'Linking sponsorship and cause related marketing: complementarities and conflicts', European Journal of Marketing, Vol. 35, No. 11/12, pp.1361-1385.

Pounder, P. (2019) 'Examining interconnectivity of entrepreneurship, innovation and sports policy framework', Journal of Entrepreneurship and Public Policy, Vol. 8, No. 4, pp. 483-499.

Porter, M. E. and Kramer, M. R. (2006) 'Strategy and society: The link between competitive advantage and corporate social responsibility', Harvard Business Review, Vol. 84, No. 12, pp.78-92.

Porter, M.E. and Kramer, M.R. (2011) 'Shared value: how to reinvent capitalism - and unleash a wave of innovation and growth', Harvard Business Review, Vol. 89, Nos. 1/2, pp.62-77.

Preuss, L., Haunschild, A. and Matten, D. (2009) 'The rise of CSR: Implications for HRM and employee representation', International Journal of Human Resource Management', Vol. 20, No. 4, pp.953-973.

Radło M-J. and Ciesielska, M-D. (2015). 'Internationalization and firm performance of companies listed at the Warsaw Stock Exchange', Ekonomika i Organizacja Przedsiębiorstwa, Vol. 11, No. 790, pp. 92-102.

Ratten, V. (2011) 'Practical implications and future research directions for international sports management', Thunderbird International Business Review, Vol. 53, No. 6, pp.763-770.

Ratten, V. and Ferreira, J. J. (Eds.). (2016). Sport Entrepreneurship and Innovation. New York, USA: Taylor \& Francis.

Ratten, V. and Babiak, K. (2010) 'The role of social responsibility, philanthropy and entrepreneurship in the sport industry', Journal of Management \& Organization, Vol. 16, No. 4, pp.482-487.

Rim, H., Kim, J. and Dong, C. (2019) 'A cross-national comparison of transparency signalling in corporate social responsibility reporting: The United States, South Korea, and China cases', Corporate Social Responsibility and Environmental Management, Vol. 26, No. 6, pp. 1517-1529.

Roome, N. (2005). 'Some implications of national agendas for CSR', in Habisch, A., Jonker, J., Wegner, M. and Schmidpeter, R. (Eds.), Corporate social responsibility across Europe, Springer, Heidelberg, pp.317-333.

Sheehy, B. (2015) 'Defining CSR: Problems and Solutions', Journal of Business Ethics, Vol. 131, No. 3, pp.625-648.

Sheth, H. and Babiak, K.M. (2010) 'Beyond the game: Perceptions and practices of corporate social responsibility in the professional sport industry', Journal of Business Ethics, Vol. 91, No. 3, pp.433-450.

Smith, A. and Westerbeek, H. (2007) 'Sport as a Vehicle for Deploying Corporate Social Responsibility', Journal of Corporate Citizenship, Vol. 25, No. 1, pp.43-54. 
Spaaij, R. and Westerbeek, H. (2010) 'Sport business and social capital: a contradiction in terms?', Sport in Society, Vol. 13, No. 9, pp.1356-1373.

Sweeney, L. and Coughlan, J. (2008) 'Do different industries report corporate social responsibility differently? An investigation through the lens of stakeholder theory', Journal of Marketing Communications, Vol. 14, No. 2, pp.113-124.

Tainsky, S. and Babiak, K. (2011) 'Professional athletes and charitable foundations: An exploratory investigation', International Journal of Sport Management and Marketing, Vol. 9, Nos. 3/4, pp.133-153.

The Economist (2008) 'The next question: does CSR work? In just good business: A special report on corporate social responsibility', The Economist, $19^{\text {th }}$ January, 2008.

Tilcsik, A. and Marquis, C. (2013). 'How mega-events and natural disasters affect corporate philanthropy in US communities', Administrative Science Quarterly, Vol. 58 No. 1, pp. 111-148.

Vanhamme, J. and Grobben, B. (2009) '"Too good to be true!". the Effectiveness of CSR history in countering negative publicity', Journal of Business Ethics, Vol. 85, Suppl. 2, pp.273-283.

Wilinski, W. (2012). 'Internationalisation through the Warsaw Stock Exchange: an empirical analysis', Post-Communist Economies, Vol. 24, No. 1, pp. 145-154.

Zeimers, G., Anagnostopoulos, C., Zintz, T. and Willem, A. (2019). 'Examining collaboration among nonprofit organizations for social responsibility programs', Nonprofit Voluntary Sector Quarterly, Vol. 48, No. 5, pp. 953-974. 